\title{
Penerapan Model Pembelajaran Kooperatif Tipe Think-Pair-Share Untuk Mengembangkan Sikap Sosial Siswa Kelas X SMA Negeri 8 Makassar (Studi pada Materi Pokok Hidrokarbon)
}

\author{
Muhammad Anwar, Sulfikar, dan Fahrul Islam \\ (Jurusan Kimia Fakultas MIPA Universitas Negeri Makassar)
}

\begin{abstract}
This research aims to know the social attitude of students after the implementation of cooperative learning model type think-pair-share (TPS) on sub topic hydrocarbon. The design of research is a one-shot case study. The indicators for the social attitudes studied are politeness, honesty, discipline, responsibility, tolerance, team working, curiosity, and communicative. The research subject is the 34 students of class $\mathrm{X}_{5}$ SMA Negeri 8 Makassar. The student's social attitude was recorded using observation sheets and peerassessment which both had been content validation. Students' achievement data was collected using an achievement test that had been content and item validation. The data was analyzed using descriptive statistics. The results shown that the students developed positive social attitudes after experiencing the cooperative learning model type TPS. Generally, each social attitude indicators increased throughout four meetings.
\end{abstract}

\section{Keywords : Social attitude, cooperative learning model type think-pair-share.}

\section{PENDAHULUAN}

Pendidikan merupakan salah satu aspek penting bagi kehidupan manusia. Pendidikan berperan sangat besar dalam membentuk karakter, perkembangan ilmu dan mental seorang anak, yang nantinya akan tumbuh menjadi seorang manusia dewasa yang akan berinteraksi dan melakukan banyak hal terhadap lingkungannya, baik secara individu maupun sebagai makhluk sosial.

Undang-Undang Republik Indonesia Nomor 20 tahun 2003 tentang Sistem Pendidikan Nasional pasal 3 menegaskan bahwa pendidikan nasional berfungsi mengembangkan kemampuan dan membentuk watak serta peradaban bangsa yang bermartabat dalam rangka mencerdaskan kehidupan bangsa, bertujuan untuk berkembangnya potensi peserta didik, agar menjadi manusia yang beriman dan bertakwa kepada Tuhan Yang Maha Esa, berakhlak mulia, sehat, berilmu, cakap, kreatif, mandiri, dan menjadi warga negara yang demokratis serta bertanggung jawab(Direktorat Pembinaan SMA, 2013). Oleh karena itu, pendidikan nasional harus berfungsi secara optimal sebagai wahana utama dalam pembangunan bangsa dan karakter peserta didik.

Berdasarkan fungsi pendidikan nasional di atas, kondisi realitas yang terjadi di lapangan sangatlah jauh dari harapan ditinjau dari sikap peserta didik.Kegaduhan praktek pendidikan terus bermunculan, seperti lulusan yang 
tidak memiliki etika, tidak berakhlak karimah, tawuran antar siswa, konsumsi narkoba, kekerasan, mencuri, dan melawan kepada guru hingga orang tua sendiri.Ditemukan juga banyak kasus-kasus kolusi, korupsi, dan nepotisme yang melibatkan orang-orang terdidik dan terpelajar.Ironisnya pula, predikat lulusan hasil pendidikan terus-menerus paling di bawah di bandingkan negara-negara tetangga (Fathurrohman, 2013).Hal ini menjadi tamparan keras bagi dunia pendidikan yang idealnya melahirkan generasi-generasi terdidik dan beretika.Soedjito (Fathurrohman, 2013) memperingatkan bahwa sikap asosial mempunyai korelasi yang tinggi dengan kejahatan.

Kecenderungan menyelesaikan persoalan dengan kekerasan dan kasus pemaksaan kehendak sering muncul di Indonesia.Kecenderungan ini juga menimpa generasi muda, misalnya pada kasus-kasus perkelahian massal.Beberapa ahli pendidikan dan tokoh masyarakat menyatakan bahwa salah satu akar masalahnya adalah implementasi kurikulum yang terlalu menekankan aspek kognitif dan keterkungkungan peserta didik di ruang belajarnya dengan kegiatan yang kurang menantang peserta didik (Kemendikbud, 2012). Oleh karena itu, pemerintah melakukan reorientasi kurikulum dari Kurikulum Tingkat Satuan Pendidikian (KTSP) ke Kurikulum 2013 sebagai salah satu upaya pemerintah dalam meningkatkan kualitas pendidikan nasional. Berdasarkan uraian fenomena dan pendapat para tokoh tersebut dapat disimpulkan bahwa tugas utama pendidikan kekinian yaitu tidak sekedar mengasah aspek pengetahuan saja tetapi juga turut andil dalam mengembangkan sikap sosial peserta didik sehingga menghasilkan karya bagi kepentingan umat manusia.

Sikap sosial merupakan sikap relatif untuk menanggapi orang lain. Timbal balik dari interaksi sosial dapat merealisasikan potensi-potensi manusia sebagai sosok individu yang utuh sebagai hasil interaksi sosial.Potensi-potensi itu pada awalnya dapat diketahui dari perilaku keseharian individu tersebut.Pada saat bersosialisasi maka yang ditunjukkannya adalah sikap sosial.Pembentukan sikap sosial seseorang dipengaruhi oleh berbagai faktor baik yang bersifat internal maupun yang bersifat eksternal (Ibrahim, 2001).

Hasil studi lapangan di SMA Negeri 8 Makassar, ditemukan permasalahan klasik yang sering terjadi dalam dunia pendidikan. Tujuan pembelajaran yang ingin dicapai khususnya pada mata pelajaran kimia kelas $\mathrm{X}$ hanya terfokus pada pencapaian aspek intelektual (ranah kognitif) semata dan kurang memperhatikan pencapaian aspek lain, seperti aspek sikap sosial siswa. Hal ini mengakibatkan sikap sosial siswa kelas $\mathrm{X}$ menjadi domain aspek tujuan pembelajaran yang terabaikan. Ditemukan juga beberapa guru yang mengeluh terkait dengan sikap sosial beberapa siswanya yang berperilaku kurang baik utamanya siswa-siswi kelas X. Beberapa keluhan terkait sikap sosial siswa tersebut, yaitu sering terlambat masuk ke kelas, perkelahian sesama teman, kurang antusias mengikuti 
pembelajaran, kurang kerja sama antar siswa, banyaknya sekat-sekat sosial yang terjadi, mementingkan diri sendiri atau geng, kurang menghargai teman bahkan kepada beberapa pengajar, dan rendahnya kepedulian siswa terhadap kebersihan lingkungan sekolah. Hal tersebut dapat menggambarkan fenomena sikap sosial siswa, khususnya siswa kelas X SMA Negeri 8 Makassar cukup mengkhawatirkan.

Oleh karena itu, perlu adanya sebuah proses pembelajaran yang tidak hanya mampu meningkatkan pengetahuan saja namun dapat pula mengembangkan sikap sosial siswa yang nantinya diwujudkan pula dalam sikap sehari-hari. Model pembelajaran yang digunakan oleh guru berpengaruh terhadap kualitas proses pembelajaran yang dilakukannya.Model pembelajaran yang diduga dapat memecahkan permasalahan di atas adalah model pembelajaran kooperatif tipe think-pair-share (TPS).

TPS mempunyai tahapan dasar yaitu siswa bekerja secara mandiri terlebih dahulu (think) yang dilanjutkan dengan bekerja kelompok secara berpasangan (pair) dan berbagi dengan seluruh kelas (share) (Uno, 2011). Tahapan tersebut menekankan siswa untuk lebih berfikir dan memberi kesempatan lebih banyak kepada setiap siswa untuk saling berinteraksi sehingga diduga selain mampu menumbuhkan sikap sosial siswa juga mampu digunakan pada materi yang menekankan suatu pemahaman, salah satunya adalah materi hidrokarbon.Hidrokarbon merupakan salah satu materi kimia yang memiliki banyak konsep seperti konsep hidrokarbon, konsep alkana, konsep alkena, konsep alkuna, konsep isomer, dan konsep reaksi hidrokarbon yang memuat aturan-aturan tertentu.Materi ini seharusnya tidak sekedar dihafal melainkan dipahami dengan baik karena materi ini adalah materi prasyarat untuk materi lanjutan seperti senyawa organik dan benzena.Sari (2014) menemukan bahwa model pembelajaran kooperatif tipe TPS bukan saja dapat meningkatkan hasil belajar, tetapi dapat pula meningkatkan sikap sosial siswa berupa sikap jujur dan tanggung jawab.

Rumusan masalah penelitian ini adalah "Apakah penerapan model pembelajaran kooperatif tipe TPS dapat melatihsikap sosialsiswa kelas $\mathrm{X}_{5}$ SMANegeri8 Makassar pada materi hidrokarbon”. Tujuan penelitian yang ingin dicapai adalah untuk mengetahui gambaran sikap sosial siswa kelas $\mathrm{X}_{5}$ SMA Negeri 8 Makassar setelah diajar melalui penerapan model pembelajaran kooperatif tipe TPSpada materi hidrokarbon. Adapun indikator sikap sosial siswa yang dikaitkan sesuai proses pembelajaran melalui penerapan model pembelajaran kooperatif tipe TPSadalah sikap sopan/santun, jujur, disiplin, tanggungjawab, toleran, kerja sama, rasa ingin tahu, dan komunikatif. 


\section{Metodologi Penelitian}

Jenis penelitian ini adalah penelitian pra-eksperimen (pre-experimental). Desain penelitian yang digunakan adalah One-Shot Case Study Design. Sugiyono (2013) menggambarkan paradigma dalam penelitian model ini dengan skema sebagai berikut:

\section{$\mathbf{X} \mathbf{O}$}

Keterangan: $\mathrm{X}=$ Penerapan model pembelajaran kooperatif tipe think-pairshare

pada materi hidrokarbon.

$\mathrm{O}=$ Observasi sikap sosial siswa dan hasil belajar siswa setelah perlakuan.

Penelitian ini dilaksanakan di SMA Negeri 8 Makassar padasemester genap tahun pelajaran 2013/2014 sebanyak 4 kali pertemuan. Subjek penelitian adalah siswa kelas $\mathrm{X}_{5}$ SMA Negeri 8 Makassar dengan jumlah siswa 34 orang.Teknik pengumpulan data menggunakan metode observasi yaitu mengamati sikap sosial siswa selama proses pembelajaran berlangsung dengan menggunakan instrumen lembar observasi yang diamati oleh tiga orang pengamat termasuk peneliti dan lembar observasi yang diamati oleh teman sejawat (peer assessment).Sebelum instrumen ini digunakan, terlebih dahulu dilakukan uji validasi isi oleh validator ahli.Data yang diperoleh dianalisis dengan menggunakan statistik deskriptif.

\section{Hasil Penelitian Dan Pembahasan}

Hasil analisis data rekapitulasi penilaian tiap indikator sikap sosial dari lembar pengamatan sikap sosial siswa dan lembar pengamatan teman sejawat (peer assessment) pada pertemuan I, II, III, dan IV disajikan pada Tabel 1.

Tabel 1. Persentase Jumlah Siswa Tiap Indikator Sikap Sosial Siswa

\begin{tabular}{|c|c|c|c|c|c|c|}
\hline \multirow{2}{*}{ No. } & \multirow{2}{*}{$\begin{array}{c}\text { Indikator Sikap } \\
\text { Sosial }\end{array}$} & \multirow{2}{*}{ Predikat } & \multicolumn{4}{|c|}{ Persentase Jumlah Siswa (\%) } \\
\hline & & & Pert. I & Pert. II & Pert. III & Pert. IV \\
\hline \multirow{4}{*}{1.} & \multirow{4}{*}{ Sopan/santun } & Sangat baik & 35.5 & 38.7 & 51.7 & 72.4 \\
\hline & & Baik & 29.0 & 29.0 & 31.0 & 13.8 \\
\hline & & Cukup & 6.5 & 19.4 & 13.8 & 10.3 \\
\hline & & Kurang & 29.0 & 12.9 & 3.5 & 3.5 \\
\hline \multirow{4}{*}{2.} & \multirow{4}{*}{ Jujur } & Sangat baik & 0.0 & 0.0 & 51.7 & 58.6 \\
\hline & & Baik & 19.4 & 19.4 & 31.0 & 24.1 \\
\hline & & Cukup & 19.4 & 19.4 & 13.8 & 13.8 \\
\hline & & Kurang & 61.3 & 61.3 & 3.5 & 3.5 \\
\hline \multirow{3}{*}{3.} & \multirow{3}{*}{ Disiplin } & Sangat baik & 9.7 & 12.9 & 13.8 & 55.2 \\
\hline & & Baik & 22.6 & 25.8 & 31.0 & 10.3 \\
\hline & & Cukup & 25.8 & 22.6 & 27.6 & 10.3 \\
\hline
\end{tabular}


Jurnal Ilmiah Kanderang Tingang 9(1) (2018) 87-96 ISSN 2087-166X

Januari-Juni 2018
Fakultas Keguruan dan Ilmu Pendidikan

Universitas Palangka Raya

Email:info@chem.upr.ac.id Web:www.chem-upr.education/ojs

\begin{tabular}{|c|c|c|c|c|c|c|}
\hline \multirow{2}{*}{ No. } & \multirow{2}{*}{$\begin{array}{c}\text { Indikator Sikap } \\
\text { Sosial }\end{array}$} & \multirow{2}{*}{ Predikat } & \multicolumn{4}{|c|}{ Persentase Jumlah Siswa (\%) } \\
\hline & & & Pert. I & Pert. II & Pert. III & Pert. IV \\
\hline \multirow{6}{*}{4.} & \multirow{6}{*}{ Tanggungjawab } & Kurang & 41.9 & 38.7 & 27.6 & 24.1 \\
\hline & & Sangat baik & 19.4 & 19.4 & 51.7 & 41.4 \\
\hline & & Baik & 12.9 & 12.9 & 24.1 & 17.2 \\
\hline & & Cukup & 29.0 & 35.5 & 13.8 & 13.8 \\
\hline & & Kurang & 38.7 & 32.3 & 10.3 & 27.6 \\
\hline & & Sangat baik & 45.2 & 45.2 & 72.4 & 82.8 \\
\hline \multirow{3}{*}{5.} & \multirow{3}{*}{ Toleran } & Baik & 32.3 & 29.0 & 17.2 & 6.9 \\
\hline & & Cukup & 16.1 & 19.4 & 10.3 & 10.3 \\
\hline & & Kurang & 6.5 & 6.5 & 0.0 & 0.0 \\
\hline \multirow{5}{*}{6.} & \multirow{4}{*}{ Kerja Sama } & Sangat baik & 6.5 & 12.9 & 34.5 & 41.4 \\
\hline & & Baik & 12.9 & 19.4 & 31.0 & 20.7 \\
\hline & & Cukup & 32.3 & 22.6 & 17.2 & 13.8 \\
\hline & & Kurang & 48.4 & 45.2 & 17.2 & 24.1 \\
\hline & \multirow{4}{*}{ Rasa Ingin Tahu } & Sangat baik & 0.0 & 3.2 & 31.0 & 6.9 \\
\hline \multirow{3}{*}{7.} & & Baik & 12.9 & 9.7 & 10.3 & 27.6 \\
\hline & & Cukup & 25.8 & 12.9 & 20.7 & 6.9 \\
\hline & & Kurang & 61.3 & 74.2 & 37.9 & 58.6 \\
\hline \multirow{4}{*}{8.} & \multirow{4}{*}{ Komunikatif } & Sangat baik & 32.3 & 16.1 & 44.8 & 41.4 \\
\hline & & Baik & 29.0 & 25.8 & 34.5 & 31.0 \\
\hline & & Cukup & 16.1 & 22.6 & 10.3 & 20.7 \\
\hline & & Kurang & 22.6 & 35.5 & 10.3 & 6.9 \\
\hline
\end{tabular}

Data Tabel 1 dapat disajikan dalam bentuk diagram batang seperti pada Gambar 1 .

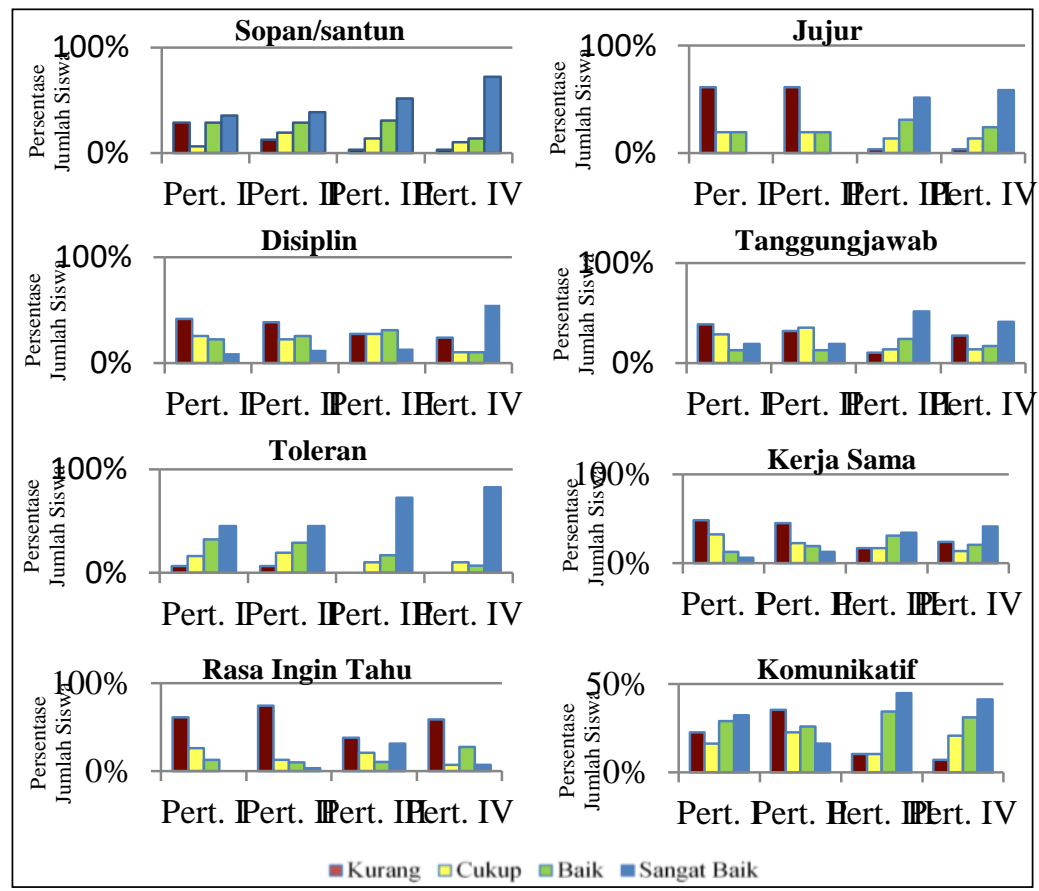

Gambar 1. Diagram Batang Persentase Jumlah Siswa Tiap Indikator Sikap Sosial 
Berdasarkan fakta yang ada di lapangan, kontribusi tahapan model pembelajaran kooperatif tipe TPS dalam melatih tiap indikator sikap sosial siswa disajikan pada Tabel 2.

Tabel 2. Kontribusi Tahapan Model Pembelajaran Kooperatif Tipe TPS dalam Melatih Sikap Sosial Siswa

\begin{tabular}{|c|c|c|c|c|}
\hline \multirow{2}{*}{ No. } & \multirow{2}{*}{$\begin{array}{c}\text { Indikator Sikap } \\
\text { Sosial }\end{array}$} & \multicolumn{3}{|c|}{ Tahap Model Pembelajaran Kooperatif Tipe TPS } \\
\hline & & Think & Pair & Share \\
\hline 1. & Sopan/santun & & $\sqrt{ }$ & $\sqrt{ }$ \\
\hline 2. & Jujur & $\sqrt{ }$ & $\sqrt{ }$ & \\
\hline 3. & Disiplin & $\sqrt{ }$ & $\sqrt{ }$ & $\sqrt{ }$ \\
\hline 4. & Tanggungjawab & $\sqrt{ }$ & $\sqrt{ }$ & $\sqrt{ }$ \\
\hline 5. & Toleran & & $\sqrt{ }$ & $\sqrt{ }$ \\
\hline 6. & Kerja Sama & & $\sqrt{ }$ & $\sqrt{ }$ \\
\hline 7. & Rasa Ingin Tahu & $\sqrt{ }$ & $\sqrt{ }$ & $\sqrt{ }$ \\
\hline 8. & Komunikatif & & $\sqrt{ }$ & $\sqrt{ }$ \\
\hline
\end{tabular}

Gambar 1 menunjukkan, sikap sopan/santun, disiplin, dan kerja sama meningkat dari pertemuan I ke pertemuan IV. Hasil ini didukung oleh kontribusi tahapan model pembelajaran kooperatif tipe think-pair-share (Tabel 2),sikap sopan/santun dilatihkan pada tahap pair dan share dimana pada tahap ini siswa saling menyampaikan pendapat dan saling memberi kesempatan menyalurkan kemampuan baik lisan maupun tulisan. Sementara itu, sikap disiplin dilatihkan pada tahap think, pair, dan share dimana pada tahap ini siswa dituntut untuk terus berada dalam tugas sesuai tahapan dan aturan yang telah ditentukan. Sementara itu pula, sikap kerja sama dilatihkan pada tahap pair dan share dimana pada tahap ini siswa dituntut untuk saling bekerja sama dalam kelompok masing-masing dan mempresentasikan hasil kerja kelompok tersebut. Di samping itu, peneliti senantiasa mengingatkan siswa untuk mewujudkan sikap sopan/santun dalam menjalin komunikasi, mengorganisir siswa agar terus berada dalam tugas, dan mengingatkan siswa untuk mewujudkan sikap kerja sama dalam menentukan penyelesaian tugas kelompok.

Hasil di atas menunjukkan bahwa sikap sopan/santun, disiplin, dan kerja sama siswa telah berhasil dilatihkan. Sholatin (2012) menemukan bahwa upaya pelatihan sikap disiplin siswa dalam pembelajaran kooperatif tipe TPS pada pertemuan I, II, III, dan IV menunjukkan rata-rata penilaian sebesar 68,67\%; 72\%; 76\%; dan 74,67\%. Mudjrimin (2013) juga menyimpulkan bahwa proses pembelajaran dengan model kooperatif tipe TPS dapat memunculkan terjadinya partisipasi siswa, komunikasi antar anggota kelompok, dan musyawarah memutuskan sesuatu. Oleh karena itu, guru dapat membina sikap sosial siswa, misalnya sikap sopan/santun dan kerja sama. 
Hasil yang berbeda untuk sikap jujur dan toleran, yaitu dari pertemuan I ke pertemuan II terlihat bahwa persentase jumlah siswa pada setiap kategori sikap jujur adalah sama sedangkan untuk sikap toleran pada kategori sangat baik juga menunjukkan persentase jumlah siswa yang sama namun menurun pada kategori baik. Hal ini disebabkan oleh data pada pertemuan I kurang akurat karena siswa masih belum terbiasa melakukan penilaian teman sejawat dan merasa takut mendapatkan nilai jelek dari hasil penilaian tersebut.Oleh karena itu, pada pertemuan II sampai IV, peneliti berusaha untuk menghilangkan rasa takut mendapat nilai jelek tersebut. Peneliti senantiasa mengingatkan siswa untuk jujur dan objektif dalam memberikan penilaian sesuai pengamatan selama proses pembelajaran berlangsung.Dengan kata lain, dapat disimpulkan bahwa sikap jujur dan toleran siswa dari pertemuan I ke pertemuan IV menunjukkan telah terjadi peningkatan. Hasil ini didukung oleh kontribusi tahapan model pembelajaran kooperatif tipe think-pair-share (Tabel 2), sikap jujur dilatihkan pada tahap think dan pair dimana pada tahap ini siswa dituntut terlebih dahulu untuk bekerja secara mandiri dan kemudian diskusi berpasangan tanpa meminta bantuan dari kelompok lain. Sementara itu, sikap toleran dilatihkan pada tahap pair dan share dimana pada tahap ini siswa saling berdiskusi dalam kelompok dan seluruh kelas.Di samping itu, peneliti senantiasa mengingatkan siswa untuk mewujudkan sikap toleran dalam menjalin komunikasi kepada teman, jujur dalam mengerjakan tugas, dan terus membimbing siswa agar terus fokus pada pengerjaan soal sehingga menghilangkan pemikiran siswa untuk menyontek.

Hasil di atas menunjukkan bahwa sikap jujur dan toleran siswa telah berhasil dilatihkan.Sari (2014) juga menemukan bahwa implementasi model pembelajaran kooperatif tipe TPS dapat meningkatkan karakter tanggungjawab siswa dari pertemuan I, II, dan III. Mudjrimin (2013) juga menyimpulkan bahwa proses pembelajaran dengan model kooperatif tipe TPS dapat memunculkan terjadinya komunikasi antar anggota kelompok, musyawarah untuk memutuskan sesuatu, menghargai kontribusi teman, dan menghormati adanya perbedaan. Oleh karena itu, guru dapat membina sikap sosial siswa, salah satunya adalah sikap toleran.

Hasil yang berbeda pula untuk sikap tanggungjawab, rasa ingin tahu, dan komunikatif, yaitu sikap tanggungjawab dan rasa ingin tahu siswa meningkat dari pertemuan I ke pertemuan III dan menurun di pertemuan IV.Sementara itu, sikap komunikatif siswa menurun dari pertemuan I ke pertemuan II lalu meningkat di pertemuan III dan menurun lagi di pertemuan IV.Penurunan sikap komunikatif dari pertemuan I ke pertemuan II selain disebabkan data pada pertemuan I kurang akurat juga disebabkan padatnya materi pembelajaran pada pertemuan II sehingga pelaksanaan tahap think, pair, dan share kurang maksimal. Hal ini tidak hanya menyebabkan sikap komunikatif menurun tetapi juga menyebabkan sikap jujur, 
disiplin, tanggungjawab, kerja sama, dan rasa ingin tahu siswa pada pertemuan II tergolong rendah. Hal ini didukung oleh data persentase jumlah siswa dengan kategori sangat baik (Tabel 1) pada pertemuan II berturut-turut yaitu 0\%; 12,9\%; $19,4 \% ; 12,9 \%$; dan 3,2\%. Hal ini sesuai penjelasan Huda (2009) bahwa salah satu kelemahan model pembelajaran kooperatif tipe TPSyaitu membutuhkan waktu pelaksanaan yang cukup lama.

Berdasarkan fakta yang ada di lapangan, penurunan sikap tanggungjawab, rasa ingin tahu, dan komunikatif pada pertemuan IV disebabkan oleh menurunnya antusiasme beberapa siswa dalam mengikuti proses pembelajaran dengan penerapan model pembelajaran kooperatif tipe TPS sehingga peneliti harus lebih banyak memberikan umpan balik yang lebih baik lagi agar siswa terus antusias mengikuti pembelajaran. Secara umum, sikap tanggungjawab, rasa ingin tahu, dan komunikatif siswa telah meningkat dari pertemuan I ke pertemuan IV. Hasil ini didukung oleh kontribusi tahapan model pembelajaran kooperatif tipe think-pairshare (Tabel 2), sikap tanggungjawab dan rasa ingin tahu dilatihkan pada tahap think, pair, dan share dimana pada tahap ini siswa dituntut untuk bertanggungjawab baik terhadap diri sendiri maupun terhadap kelompok dalam mengerjakan dan menyelesaikan soal latihan. Sementara itu, sikap komunikatif dilatihkan pada tahap pair dan share dimana pada tahap ini siswa dituntut untuk saling berbagi pendapat. Di samping itu, peneliti senantiasa mengingatkan siswa akan pentingnya mewujudkan sikap tanggungjawab dan komunikatif, membimbing dan memantau kerja siswa agar tidak melalaikan tanggungjawabnya untuk mengerjakan soal latihan, dan memberikan umpan balik untuk mengaktifkan dan memancing rasa ingin tahu siswa.

Hasil di atas menunjukkan bahwa sikap tanggungjawab, rasa ingin tahu, dan komunikatif siswa telah berhasil dilatihkan.Sari (2014) juga menemukan bahwa implementasi model pembelajaran kooperatif tipe TPS dapat meningkatkan karakter tanggungjawab siswa dari pertemuan I, II, dan III. Mudjrimin (2013) juga menyimpulkan bahwa proses pembelajaran dengan model kooperatif tipe TPS dapat memunculkan terjadinya partisipasi siswa, komunikasi antar anggota kelompok, dan musyawarah untuk memutuskan sesuatu. Oleh karena itu, guru dapat membina sikap sosial siswa, misalnya sikap rasa ingin tahu dan komunikatif.

\section{Kesimpulan}

Berdasarkan hasil penelitian dan pembahasan, maka dapat disimpulkan bahwa sikap sosial siswa berkembang dengan positif setelah diajar melalui penerapan model pembelajaran kooperatif tipe think-pair-share. Hal ini didukung data tiap indikator sikap sosial yaitu sopan/santun, jujur, disiplin, tanggungjawab, toleran, kerja sama, rasa ingin tahu, dan komunikatif yang secara umum 
menunjukkan peningkatan dari pertemuan I ke pertemuan IV. Selain itu, siswa juga memiliki kemampuan kognitif yang baik dilihat dari hasil analisis data tes hasil belajar yang relatif tinggi.

\section{Saran}

Adapun saran yang bisa dikemukakan oleh peneliti adalah sebagai berikut:

1. Model pembelajaran kooperatif tipe think-pair-share diharapkan dapat dijadikan alternatif model pembelajaran selain untuk meningkatkan hasil belajar juga untuk melatih sikap sosial siswa.

2. Peneliti yang ingin mengkaji penelitian serupa agar melakukan penelitian dengan memperhitungkan waktu pelaksanaan sebaik mungkin agar pembelajaran terlaksana dengan baik. Selain itu, agar menerapkan model pembelajaran kooperatif tipe think-pair-share dengan maksimal 4 pertemuan saja secara berturut-turut. Setelah itu, agar variatif dalam menerapkan model pembelajaran lain untuk menghindari turunnya sikap antusias dan komitmen siswa dalam mengikuti setiap proses pembelajaran.

\section{Daftar Pustaka}

Direktorat Pembinaan SMA. 2013. Model Penilaian Hasil Belajar Peserta Didik SMA. Kementerian Pendidikan dan Kebudayaan RI.Diakses 10 Januari 2014.http://sman1pare.sch.id/wp-content/uploads/2013/10/MODEL-PENILHSL-BEL-SMA.pdf

Faturrohman, P, Suryana, dan Fenny F. 2013. Pengembangan Pendidikan Karakter. Bandung: PT Refika Aditama.

Ibrahim, R. 2001. Pembinaan Perilaku Sosial Melalui Pendidikan Jasmani: Prinsip-prinsip dan Metode. Jakarta: Dirjen Olahraga Depdiknas.

Kemendikbud. 2012.Dokumen Kurikulum 2013. Kementerian Pendidikan dan Kebudayaan RI.Diakses 10 Januari 2014.http://tania.fkip.uns.ac.id/wpcontent/uploads/dokumen-kurikulum-2013.pdf

Mudjrimin, I. W. Lasmawan dan A.A.I.N. Marhaeni. 2013. Pengaruh Model Pembelajaran Kooperatif Tipe Think Pair Share terhadap Motivasi Berprestasi dan Hasil Belajar IPS Siswa Kelas V SDN GUGUS 02 KOPANG.e-Journal Program Pascasarjana Universitas Pendidikan Ganesha, Volume 3. Diakses 10 Januari 2014.http://pasca.undiksha.ac.id/ejournal/index.php/jurnal_pendas/article/download/775/560 
Sari, N. K. dan Muchlis. 2014. Implementasi Model Pembelajaran Kooperatif Tipe TPS dengan Pendekatan Kontekstual untuk Melatih Sikap Jujur dan Tanggung Jawab Siswa Kelas XI IPA pada Materi Kesetimbangan Kimia di SMA Negeri 1 Slahung Ponorogo.Unesa Journal of Chemical Education, Vol. 3 , No. 1 , pp. 10-20 Januari 2014. Diakses 10 Januari 2014.http://ejournal.unesa.ac.id/article/9488/36/article.pdf

Sholatin, A. dan Leny Y. 2012.Pelatihan Tanggung Jawab dan Disiplin Siswa dalam Pembelajaran Kooperatif Tipe Think-Pair-Share (TPS) Materi Sistem Koloid. Unesa Journal of Chemical Education, Vol. 1, No. 2, pp. 1-6 September 2012, ISSN: 2252-9454. Diakses 10 Januari 2014.http://ejournal.unesa.ac.id/_index.php/journal-of-chemicaleducation/article/view/269

Sugiyono. 2013. Metode Penelitian Pendidikan (Pendekatan Kuantitatif, Kualitatif dan $R \& D)$. Bandung: CV ALFABETA.

Uno, B. H. dan Nurdin. 2011. Belajar dengan Pendekatan PAILKEM. Jakarta: Bumi Aksara. 